Yol.2 2Nn. I لanuari 2019

ISSN 2614-2775

e-ISSN 2621-8143

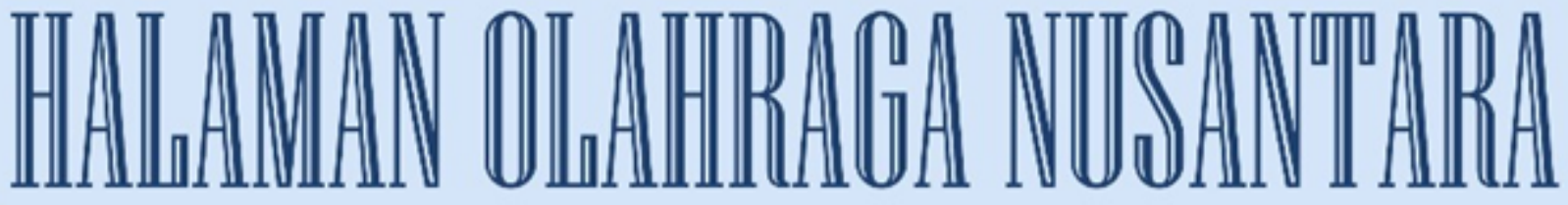

Surnal @lmu Xeolahragaan

Diterbitkan Oleh:

Program Studi Pendidikan Olahraga

Fakultas Keguruan dan Ilmu Pendidikan

Universitas PGRI Palembang

Jurnal

Volume Nomor Halaman Palembang ISSN/e-ISSN

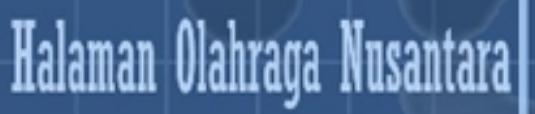

\begin{tabular}{l|l|l|l}
2 & 1 & $1-96$ & 2019
\end{tabular}




\section{Halaman Olahraga Nusantara}

Jurnal Ilmu Keolahragaan

Volume 2, Nomor 1, Januari 2019

Pelindung/Penasehat

Dr. H. Bukman Lian, M. M., M. Si.

Penanggung Jawab

Dr. Dessy Wardiah, M. Pd.

Ketua Dewan Redaksi

Farizal Imansyah, M. Pd.

Wakil Ketua Dewan Redaksi

Ilham Arvan Junaidi, M. Pd.

Sekretaris

Bayu Iswana, M. Pd.

Penyunting Pelaksana

Rafel Orlando, M. Pd.

Ardo Okilanda, M. Pd.

Daryono, M. Pd.

\section{Mitra Bestari}

Prof. Dr. A. Sofyan Hanif, M. Pd (Universitas Negeri Jakarta)

Dr. Sukirno (Universitas Sriwijaya)

Dr. Ronni Yenes, M. Pd (Universitas Negeri Padang)

Dr. Benny, M. Pd. (Universitas Negeri Makasar)

Dr. Putri Cicilia Kristina, M. Pd (Universitas PGRI Palembang)

\section{Tata Usaha}

M. Taheri Akbar, M. Pd.

Widya Handayani, S. Pd., M. Si.

Setting:

Dede Dwiansyah Putra, M. Pd.

Alamat Redaksi:

Prodi Pendidkan Olahraga Fakultas Keguruan Ilmu dan Pendidikan Universitas PGRI Palembang

Jl. Jendral A. Yani Lorong Gotong Royong 9/10 Ulu Palembang

Telp. 0711-510043, Fax. 0711-514782

e-mail jurnal: jurnalhonupgripalembang@gmail.com

e-mail : ardo.oku@univpgri-palembang.ac.id

website: univpgri-palembang.ac.id 
Halaman Olahraga Nusantara (Jurnal Ilmu Keolahragaan)

P-ISSN 2614-2775

Volume 2, No. 1, Januari 2019

E-ISSN 2621-8143

\section{DAFTAR ISI}

Hasil Penelitian

Halaman

Pengaruh Metode Rangkaian Bermain Terhadap Keterampilan Dasar Olahraga Panahan Siswa Ektrakulikuler Sit (Sekolah Islam Terpadu) Auladi Palembang

- Arisman

Penerapan Metode Bermain Dalam Meningkatkan Hasil Belajar Guling Depan (Forward Roll)

- Ruslan, M. Samsul Huda

Survei Tingkat Kesegaran Jasmani pada Peserta Ekstrakulikuler Sepakbola Di Sma Negeri 2 Oku

- Daryono

Kontribusi Daya Ledak Tungkai dan Keseimbangan Terhadap Kemampuan Lompat Jauh Murid Sd Negeri 139 Sinjai

- Adam Mappaompo

Survei Tingkat Kebugaran Jasmani Mahasiswa Pendidikan Olahraga Angkatan 2017 Stkip Pgri Bangkalan

- Heni Yuli Handayani .

Profil Delayed Onset Muscle Soreness (Doms) pada Mahasiswa Fik Unp Setelah Latihan Fisik

- Heru Syarli Lesmana

Perbedaan Pengaruh Latihan Menggunakan Karet dengan Menggunakan Dumbbell $1 \mathrm{Kg}$ Terhadap Kecepatan Pukulan Oi Tsuki

Chudan pada Atlet Karate Putra Perguruan Wadokai Dojo Sma Negeri 11 Medan Tahun 2017

- Pangondian Hotliber Purba $60-71$

Tinjauan Kondisi Fisik Atlet Sepakbola Kabupaten Kerinci Dalam

Rangka Persiapan Mengikuti Porprov Xxii Bungo Tebo 2018

- Palmizal, Wawan Junresti Daya, dan Sri Murniati

Aktivitas Jasmani dan Persepsi Gerak Anak Usia Dini

- Dian Pujianto 
Peningkatan Keterampilan Bermain Bolabasket Mahasiswa Melalui Latihan Aktifitas Maze Perkuliahan Permainan Bolabasket

- Ilham Arvan Junaidi dan Rury Rizhardy $88-96$ 


\title{
PENINGKATAN KETERAMPILAN BERMAIN BOLABASKET \\ MAHASISWA MELALUI LATIHAN AKTIFITAS MAZE PERKULIAHAN PERMAINAN BOLABASKET
}

\author{
Oleh: Ilham Arvan Junaidi dan Rury Rizhardy \\ (Dosen Universitas PGRI Palembang)
}

\begin{abstract}
Abstrak
Keterampilan mahasiswa dalam mata kuliah permainan bolabasket masih rendah. Melihat permasalahan tersebut penelitian ini dirumuskan untuk melihat Peningkatan Keterampilan bermain Bolabasket Mahasiswa Melalui Latihan Aktifitas Maze Perkuliahan Permainan Bolabasket. Tujuan dari penelitian ini adalah mahasiswa mampu menguasai keterampilan permainan bolabasket serta mendapatkan hasil belajar yang optimal. Metode penelitian yang digunakan adalah penelitian pre-experiment dengan jenis the one group pretest-posttest design yang bertujuan melihat peningkatan hasil bejajar matakuliah permainan bolabasket setelah diberikan bentuk latihan aktifitas maze dan melihat mutu hasil belajar mata kuliah tersebut sebelum dan sesudah diberi bentuk latihan aktifitas maze. Subjek penelitian adalah 40 orang mahasiswa yang mengambil mata kuliah permainan bolabasket, subjek penelitian ditetapkan dengan pertimbangan kelas yang memiliki masalah keterampilan bermain bolabasket. Teknik pengumpulan data dengan menggunakan tes keterampilan bermain bolabasket. Data yang diperoleh dianalisis dengan menggunakan uji perbedaan dua rata-rata sampel yang saling berhubungan (paired sample t-tes) dengan menggunakan bantuan program Statistical Product and Service Solution (SPSS) versi 15.0. Hasil penelitian menunjukan bahwa terdapat peningkatan keterampilan bermain bola basket mahasiswa melalui latihan aktifitas maze pada perkuliahan bola basket.
\end{abstract}

Kata Kunci: Keterampilan Bermain Bolabasket, Mahasiswa, Latihan Aktifitas Maze

\section{IMPROVING STUDENTS 'SKILLS TO PLAY BASKET BALL THROUGH MAZE ACTIVITIES EXERCISES OF BASKETBALL GAMES}

\begin{abstract}
The basketball game is one of the lecture materials that must be mastered by students who can later become students in teaching at the school level. But the skills of students in the basketball game course are still low. Seeing this problem, this research was formulated to see the improvement of students' playing skills in Basketball through the activities of Maze lectures on basketball games. The purpose of this study is that students are able to master basketball game skills and get optimal learning outcomes. In addition, it is also hoped that in this study it will be useful for students to improve their mastery of basketball game subjects.
\end{abstract}


The research method used is a pre-experiment study with the type of one group pretest-posttest design which aims to see an increase in the results of the basketball game subjects. form a maze activity exercise and see the quality of the learning outcomes of the course before and after being given a form of maze activity training. The research subjects were 40 students who took basketball game subjects, the subject of the study was determined by the consideration of the class who had the problem of playing basketball skills. Data collection techniques using basketball playing skills test. The data obtained were analyzed using a paired sample t-test of two average sample differences using the Statistical Product and Service Solution (SPSS) program version 15.0. The results showed that there was an increase in student basketball playing skills through maze activity training in basketball lectures.

Keyword: Basketball Skill, Student, Maze Actifity

\section{A. PENDAHULUAN}

Pendidikan adalah menentukan arah pembinaan dan pembangunan kepribadian termasuk perubahan prilaku, selain itu pendidikan juga dapat diartikan sebagai suatu sektor yang mempunyai peranan penting dalam membangun manusia indonesia seutuhnya yang sejalan dengan tujuan nawacita pemerintah, dengan pendidikan manusia untuk belajar aktif serta mengerahkan semua potensi yang ada dalam diri individu tersebut sebagaimana yang dirumuskan dalam Undang-Undang Republik Indonesia Nomor 20 Tahun 2003 tentang Sistem Pendidikan Nasional.

Untuk dapat mencapai tujuan pendidikan tersebut, lembaga pendidikan merupakan salah satu lembaga yang bertanggung jawab untuk mengeksplorasi semua potensi, kreativitas, keterampilan-keterampilan, dan bakat yang dimiliki peserta didik khususnya olahraga. Salah satu materi pelajaran yang dijarkan disekolah adalah Pendidikan Olahraga. Salah satu cabang dari olahraga yang ada pada kurikulum sekolah adalah permainan bolabasket, permainan bolabasket adalah salah satu mata kuliah program studi pendidikan olahraga, yang pembahasannya mencakup tentang keterampilan dasar dalam bermain bolabasket seperti, mengoper (passing), menggiring (dribbling), menembak (shooting), gerakan kaki (foot work), dan beberapa teknik lainnya.

Selain itu, penguasaan materi mata kuliah permainan bolabasket diperlukan metode yang efektif dan efisien, terutama dalam penggunaan metode 
latihan. Metode latihan adalah cara-cara yang terencana secara sistematis dan berorientasi kepada tujuan (Harsono. 2015:21).

Matakuliah permainan bolabasket adalah mata kuliah praktikum disemester IV dengan beban kredit sebanyak dua SKS. Berdasarkan wawancara nonformal kepada mahasiswa program studi pendidikan olahraga yang pernah mengikuti matakuliah ini, mata kuliah ini termasuk kategori matakuliah yang sulit dikuasai, karena didominasi dengan gerakan-gerakan dinamis yang membutuhkan persepsi gerak yang baik.

Perbasi (2010:1) Bolabasket merupakan cabang olahraga yang dimainkan oleh dua regu. Masing-masing regu terdiri dari lima orang pemain yang berusaha memasukkan bola ke keranjang lawan atau membuat skor. Dalam pelaksanaan permainan bolabasket, setiap pemain dapat memainkan bola dengan memakai satu atau dua tangan dengan cara bola dioper, dilempar sesuai peraturan dan ketentuan yang berlaku.

Jika ingin melakukan tusukan dan menerobos ke daerah lawan maka harus mempunyai kemampuan menggiring (dribble) bola yang baik pula. Apabila gerakan telah dilakukan dengan baik, maka akan menghasilkan efisiensi dalam kerja. Jika didukung dengan latihan yang teratur dan terprogram, maka efektifitas akan didapatkan dengan baik juga. Apabila seorang pemain atau regu menginginkan tim yang baik dan solid serta dapat menghasilkan prestasi yang memuaskan, maka pemain dituntut untuk dapat melakukan berbagai unsur gerak tersebut dengan baik.

Passing merupakan upaya seorang pemain melemparkan bola untuk diberikan kepada teman setimnya untuk ditangkap dan selanjutnya dimainkan sesuai dengan situasi dan kondisi yang diinginkan bahkan berpeluanga untuk menghasilkan poin. Prinsip-prinsip pokok passing penting dipahami dan dimengerti oleh setiap pemain bolabasket. Kesalahan passing akan sangat merugikan timnya, bola dapat direbut oleh lawan dan siap untuk melakukan serangan balik.

Dribble membantu memindahkan bola di lapangan dengan menjauhkan diri dari penjagaan. Setiap tim butuh paling tidak satu pendribble ahli yang dapat 
membawa bola dengan cepat di lapangan pada suatu terobosan cepat (fast break) dan melindunginya terhadap penjagaan. Belajar bagaimana cara melakukan dribble sama pentingnya dengan belajar mengetahui kapan menggiring bola harus dilakukan. Karena sering terjadi dalam sebuah permainan, apabila terlalu banyak dribble justru akan merusak kerangka kerja suatu permainan regunya.

Menembak merupakan sasaran akhir setiap permainan. Keberhasilan suatu regu dalam permainan selalu ditentukan oleh keberhasilannya dalam menembak. Untuk dapat berhasil dalam tembakan dan menghasilkan poin perlu dilakukan teknik-teknik yang benar. Apabila pemain menguasai teknik tembakan yang bagus maka akan memaksa lawan untuk menempel dengan ketat dan mudah untuk dikecoh, serta memudahkan pemain untuk mengoper dan menggiring bola serta menembak. Apabila pemain belum menguasai tembakan yang akurat, lawan akan mudah untuk mengantisipasi passing, giringan bola dan menjadi lebih sulit untuk dikecoh. Pemain yang tidak memiliki teknik tembakan yang baik maka harus memiliki teknik lain yang lebih menonjol agar kebutuhan tim terpenuhi.

Aktivitas maze itu adalah suatu proses kegiatan yang membingungkan, Ditambahkan oleh Fleck dan Quinn (2007:57) bahwa dalam aktivitas maze, pemain harus bergerak keseluruh arah untuk memecahkan berbagai masalah ruang yang membingungkan. Tujuan dari aktivitas-aktivitas di sini adalah untuk memberikan kesempatan bagi para pemain untuk bergerak ke berbagai arah, memecahkan masalah gerak baik secara perorangan maupun kolektif, dan merasakan mengolah bola dalam berbagai situasi yang membingungkan.

\section{B. METODE PENELITIAN}

Jenis penelitian yang digunakan dalam penelitian ini adalah penelitian pre eksperimen dengan bentuk rancangan the one group pre test - post test design. Penelitian ini akan melihat apakah dengan latihan aktifitas maze dapat meningkatkan keterampilan bermain bolabasket mahasiswa pada perkuliahan permainan bolabasket secara signifikan, hal ini dilakukan dengan membandingkan hasil pre test dan post test keterampilan belajar mahasiswa setelah diberikan latihan aktifitas maze. 
Populasi dalam penelitian ini adalah mahasiswa semester III (tiga) yamng mengambil mata kuliah permainan bolabasket yang berjumlah 324 orang mahasiswa. Sedangkan untuk teknik penarikan sampel menggunakan teknik purposive sampling, yaitu seluruh mahasiswa yang mengambil seksi perkuliahan yang dibina peneliti berjumlah 40 orang.

Dalam melakukan penelitian ini data yang diperlukan diungkapkan dengan mengunakan tes Keterampilan Bermain Bolabasket dari Nurhasan (2007:213). Keterampilan yang akan diukur adalah 1) Kemampuan Passing (memantulkan bola ke dinding tembok); 2) Kemampuan Dribbling ( Menggiring Bola); 3) Kemampuan Shooting (tes menembak selama satu menit). Untuk menguji signifikansi perbedaan antara hasil pretest dan posttest keterampilan mencatat, maka digunakan rumus uji t ( $\mathrm{t}$-test ), sesuai dengan pendapat Thomas, dkk. (2015: 198) yang mengatakan bahwa "efektifitas atau pengaruh dari perlakuan dilihat dari perbedaan antara pretest dan post test dengan menggunakan analisis statistik dengan $t$-test sample dependent.

\section{HASIL PENELITIAN DAN PEMBAHASAN}

Pengolahan data penelitian disajikan secara berurutan dapat dilihat pada tabel sebagai berikut.

\section{Tabel 1. Rata Hitung dan Standar Deviasi Data Penelitian}

\begin{tabular}{|c|c|c|c|c|c|}
\hline Variabel & $\mathrm{N}$ & $X$ & Std.dev $\bar{x}$ & Min & Max \\
\hline Pre Test & 40 & 49,47 & 0,76 & 48,80 & 49,74 \\
\hline Post Test & 40 & 51,86 & 0,85 & 50,45 & 53,61 \\
\hline
\end{tabular}

Uji normalitas data dianalisis dengan statistik uji Lilliefors, dengan taraf signifikansi yang digunakan sebagai dasar menolak ataupun menerima keputusan normal atau tidaknya suatu distribusi data adalah $\alpha>0,05$. Dari hasil pengolahan data uji Normalitas dengan Uji Liliefors diperoleh angka normalitas distribusi data seperti pada tabel berikut : 
Tabel 2. Rangkuman Hasil Pengujian Normalitas Data

\begin{tabular}{lcccccc}
\hline \multicolumn{7}{c}{ Tests of Normality } \\
\hline \multicolumn{7}{c}{ Kolmogorov-Smirnov } \\
\hline & Statistic & df & Sig. & Statistic & df & Sig. \\
\hline $\begin{array}{l}\text { pre_tes } \\
\mathrm{t}\end{array}$ & .183 & 40 & .002 & .851 & 40 & .000 \\
$\begin{array}{l}\text { post_te } \\
\text { st }\end{array}$ & .152 & 40 & .021 & .922 & 40 & .009 \\
\hline \begin{tabular}{l} 
a. Lilliefors Significance Correction \\
\hline
\end{tabular}
\end{tabular}

Uji statistik yang digunakan adalah t-test. Adapun Hasil pengujian Hipotesis di sajikan dalam tabel 10 berikut ini:

Tabel 3. Rangkuman Hasil Pengujian Hipotesis

Paired Samples Test

\section{Paired Differences}

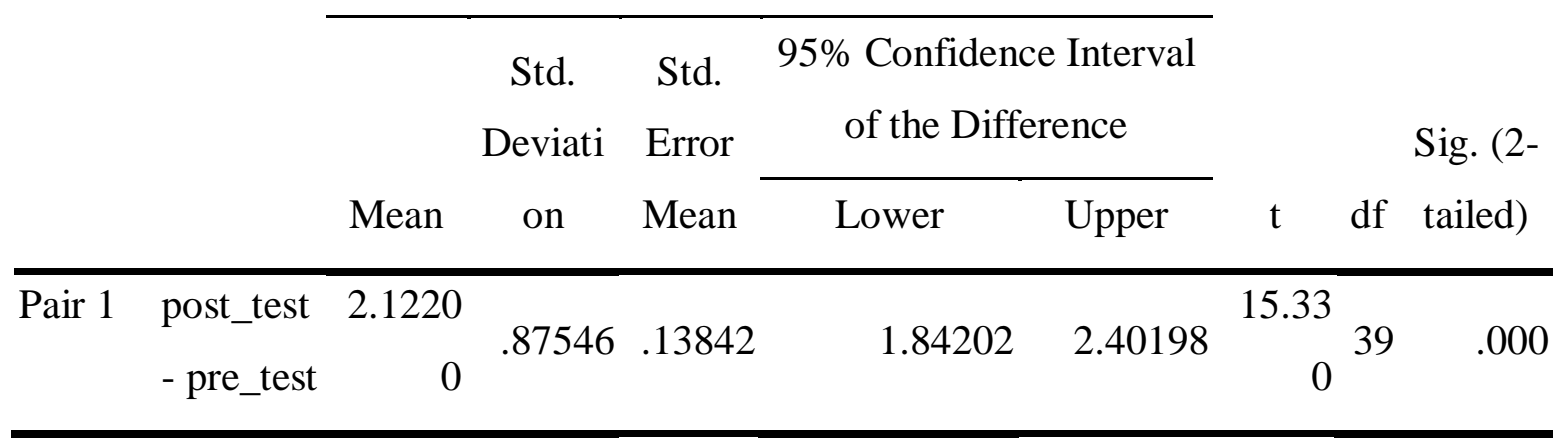

Berdasarkan tabel 3 dapat dilihat bahwa $t_{\text {hitung }}(15,330)>t_{\text {tabel }}(1,68)$. Hal ini berarti bahwa hipotesis penelitian dapat diterima. Dengan demikian dapat disimpulkan bahwa aktivitas maze memberikan peningkatan yang signifikan terhadap keterampilan bermain bolabasket. Pada hasil kelompok yang berlatih dengan menggunakan aktivitas maze terhadap peningkatan keterampilan bermain bolabasket dari tes awal dan tes akhir terjadi peningkatan sebesar 2,12, yaitu dari skor rata-rata 49,74 pada pre test menjadi 51,86 pada post test. Hal ini berarti hipotesis penelitian yang mengatakan aktivitas maze memberikan pengaruh yang signifikan terhadap peningkatan keterampilan bermain bolabasket dapat diterima kebenarannya. Terjadinya peningkatan ini kemungkinan disebabkan oleh adaptasi 
atlet terhadap suasana latihan yang telah dibuat dan dilakukan secara berulangulang sehingga pengorganisasian alat gerak menjadi semakin baik.

Hasil penelitian menunjukkan bahwa latihan menggunakan aktivitas maze, memang dapat meningkatkan keterampilan bermain bolabasket, namun peningkatan yang diharapkan telah maksimal. Menurut Syafruddin (2011:22) "training olahraga mempunyai tugas utama yaitu untuk mengembangkan dan meningkatkan kemampuan yang dimiliki para atlet baik dalam arti kemampuan fisik maupun mental".

Berkaitan dengan hal tersebut latihan dengan menggunakan aktivitas maze bertujuan untuk meningkatkan keterampilan bermain bolabasket. Dalam usaha meningkatkan keterampilan bermain bolabasket, aktivitas maze sangat cocok dilakukan. Dengan banyak pengulangan akan memberikan rangsangan terhadap pengorganisasian alat gerak akan maksimal. Apabila pengorganisasian alat gerak baik, maka akan berdampak bagus terhadap pelakasanaan teknik dasar bolabasket seorang pemain (Junaidi, 2018). Dengan pengorganisasian alat gerak bagus ini akan menunjang terhadap pencapaian prestasi yang diinginkan.

Aktivitas maze merupakan salah satu bentuk latihan dengan menggunakan permainan kecil yang dimana pemain harus bergerak kesegala arah dalam memecahkan berbagai masalah diruang tertentu. Aktivitas maze bertujuan untuk memberikan kesempatan para pemain untuk bergerak keberbagai arah dan memecahkan masalah gerak secara perorangan maupun secara kolektif, dan merasakan mengolah bola dalam berbagai situasi.

Aktivitas maze adalah termasuk juga salah satu bentuk permainan kecil yang dimana dalam kegiatan latihannya menuntut atlet harus bergerak kesegala arah untuk memecahkan berbagai masalah ruang. Latihan dengan aktivitas maze dilakukan secara berulang-ulang. Selain dapat meningkatkan keterampilan bermain bolabasket, latihan dengan aktivitas maze juga akan membiasakan seorang pemain untuk beraktivitas pengorganisasian alat gerak. Apabila latihan tidak dilakukan secara teratur dan berkelanjutan, maka tidak dapat memperbaiki keterampilan bermain bolabasket pemain sehingga akan mempengaruhi penampilan pemain dalam suatu pertandingan. 
Dalam hal ini pendekatan aktivitas maze juga tidak begitu saja diabaikan, karena bagaimanapun hasil dalam penelitian ini juga menemukan peningkatan dari keterampilan bermain bolabasket dengan menggunakan aktivitas maze. Selain itu aktivitas maze juga bisa membiasakan pemain untuk bergerak terus-menerus seperti dalam permainan boala basket.

\section{SIMPULAN}

Berdasarkan analisis data dan pembahasan yang telah dipaparkan terdahulu, maka dapat dikemukakan beberapa kesimpulan terdapat peningkatan keterampilan bermain bolabasket mahasiswa melalui latihan aktifitas maze perkuliahan permainan bolabasket, dimana hasil yang diperoleh $t_{\text {hitung }}>t_{\text {tabel }}=$ $15,33>1,68$.

\section{DAFTAR PUSTAKA}

A.Muri Yusuf. 2005. Metodelogi Penelitian. Padang: UNP Press.

Ahmadi, N. 2007. Permainan Bolabasket. Solo: Era Intermedia.

Fleck, T dan Quinn, R. 2007. Panduan Latihan Bola Basket Andal. Jakarta: PT. Sunda Kelapa Pustaka

Giriwijoyo, S dan Sidik, D.Z. 2012. Ilmu Kesehatan Olahraga. Bandung: Remaja Rosdakarya

Harsono.2015. Kepelatihan Olahraga Teori dan Metodologi. Bandung: Rosda Junaidi, Ilham Arvan (2018) Peningkatan Keterampilan Chest Pass Bola Basket Melalui Metode Peer Teaching Mahasiswa Program Studi Pendidikan Olahraga. Jurnal Penjaskesrek. 5(1): 37-44.

Nurhasan, Cholil (2007). Tes dan Pengukuran. Bandung: FPOK UPI Bandung Perbasi. 2010. Terjemahan Peraturan Permainan Bolabasket. Jakarta: PB Perbasi

Pusat Pembinaan dan Pengembangan Bahasa. 2015. Kamus Besar Bahasa Indonesia. Jakarta: Balai Pustaka

Sukadiyanto. 2005. Pengantar Teori Metodologi Melatih Fisik. Yogyakarta: UNY 
Syafruddin. (2011). Ilmu Kepelatihan Olahraga Teori dan Aplikasinya Dalam Pembinaan Latihan. Padang: UNP Press Padang.

Thomas. J.R. dkk . 2015. Research Methods in Physical Activity-7th Edition. Illinois: Human Kinetics. 


\section{GAYA SELINGKUNG}

1. Jurnal Halaman Olahraga Nusantara menerbitkan karya ilmiah dan hasil penelitian dalam seluruh kajian ilmu keolahragaan, baik pendidikan, kepelatihan, dan lainya dalam pengembangan teori dan konsep yang belum pernah dipublikasikan. Jurnal ini memuat (1) kumpulan informasi baru, (2) hasil objektif dari suatu kajian ilmu keolahragaan, dan (3) rekomendasi.

2. Penulisan naskah menggunakan bahasa Indonesia secara benar. Panjang naskah antara 7-20 halaman, kertas ukuran quarto, diketik 1,5 spasi, tipe huruf Times New Roman, ukuran huruf 12, margin atas dan kiri 4 cm, kanan dan bawah $3 \mathrm{~cm}$.

3. Naskah ditulis dengan sistematika dan ketentuan sebagai berikut.

a. Judul: ditulis dengan singkat, padat, terdiri dari 5-15 kata, dan menggunakan bahasa Indonesia, harus mencerminkan substansi keilmuan yang diuraikan pada batang tubuh artikel. Judul utama (main title) dan anak judul (subtitle) dipisahkan dengan dua titik. Judul artikel dicetak 15 mm dibawah tepi atas, dengan huruf capital-kecil tebal. Judul subbab peringkat 1 dicetak capital semua, rata tepi kiri, tebal, peringkat 2 dicetak capital kecil, rata tepi kiri, tebal; peringkat 3 dicetak kapital-kecil, rata tepi kiri, miring-tebal.

b. Nama penulis: Nama penulis artikel ditulis tanpa disertai gelar akademik atau gelar apapun. Nama lengkap dengan gelar akademik boleh ditulis disebelah bawah halaman pertama artikel. Nama lembaga tempat bekerja penulis juga dibuat sebagai catatan kaki dihalaman pertama. Jika lebih dari tiga penulis, hanya penulis utama saja yang dicantumkan dibawah judul; nama penulis lain ditulis dalam catatan kaki.

c. Abstrak artikel kajian ilmiah/ konseptual adalah ringkasan dari isi artikel yang dituangkan secara padat menggunakan bahasa Indonesia dan bahasa inggris. Abstrak hasil penelitian memuat masalah atau tujuan, metode, dan hasil penelitian. Abstrak terdiri dari 100-300 kata yang disusun dalam satu 
paragraph dengan format esei bukan enumeratif, dan diketik dengan spasi tunggal serta dengan format yang lebih sempit dari teks utama.

d. Kata Kunci terdiri dari 3-5 kata, yaitu istilah-istilah yang mewakili ide atau konsep dasar yang dibahas dalam penulisan karya ilmiah. Kata kunci lazimnya berupa kata dasar atau kata yang berdiri sendiri (tunggal) bukan rangkaian kata.

e. Naskah hasil penulisan ditulis dengan urutan (1) judul, (2) nama penulis, (3) abstrak, (4) kata kunci, (5) bagian pendahuluan yang harus di akhiri dengan rumusan singkat (1-2 kalimat) tentang hal-hal pokok yang akan dibahas dan tujuan dari pembahasan. Untuk artikel hasil penelitian berisi (a) rumusan masalah, (b) tujuan, dan (c) deskripsi singkat mengenai kerangka pemikiran dalam pendahuluan, (6) isi memuat (a) metode penelitian, (b) hasil penelitian, dan (c) pembahasan. (8) simpulan dan saran, (9) daftar pustaka.

f. Naskah diluar hasil penelitian ditulis dengan urutan (1) judul, (2) nama penulis, (3) abstrak, (4) kata kunci, (5) pendahuluan yang memuat latar belakang dan rumusan masalah, (6) isi, (7) simpulan, dan (8) daftar pustaka.

g. Table dan gambar/ bagan di usahakan dicetak dalam satu halaman, nomor dan judul table dan gambar dicetak di atas table dengan huruf tebal. Isi dalam table dicetak dengan huruf normal (tidak tebal). Table hanya menggunakan garis horizontal (horizontal border)

h. Penulisan daftar pustaka

1) Buku ditulis dengan urutan: (a) nama akhir, (b) koma, (c) nama depan penulis, (d) titik, (e) tahun penerbitan, (f) titik, (g) judul buku dalam huruf miring, (h) titik, (i) edisi jika ada, (j) titik, (k) kota penerbitan, (l) titik dua, (m) nama penerbit, dan (n) titik.

2) Artikel ditulis dengan urutan: (a) nama akhir, (b) koma, (c) nama depan penulis, (d) titik, (e) tahun penerbitan, (f) titik, (g) tanda petik dua, (h) judul artikel, (i) titik, (j) tanda petik tutup, (k) nama jurnal dalam cetak miring, (l) volume, (m) nomor, dan (n) titik. Apabila artikel diterbitkan 
disuatu buku, tulis kata "dalam" sebelum nama editor buku tersebut, dan buku harus ditulis didalam daftar pustaka.

3) Skripsi, thesis, atau disertasi ditulis dengan urutan: (a) nama akhir, (b) koma, (c) nama depan penulis, (d) titik, (e) tahun, (f) titik, (g) judul dalam huruf miring, (h) skripsi/thesis/disertasi pada (nama perguruan tinggi yang bersangkutan), (i) nama kota, (j) titik dua, (k) tulisan "tidak diterbitkan", dan (1) titik. 